\title{
Ernesto Bozzano on the Phenomena of Bilocation
}

\author{
Carlos S. Alvarado, Ph.D. \\ University of Virginia
}

\begin{abstract}
Italian psychical researcher Ernesto Bozzano (1862-1943) was a well-known student of parapsychological phenomena and a strong defender of the concept of survival of bodily death. This paper includes an excerpt of what Bozzano referred to as the phenomena of bilocation, a term he used for the phantom limb sensations experienced by amputees, autoscopy, out-of-body and near-death experiences (OBEs and NDEs), and a variety of luminous or cloud-like emanations that clairvoyants claimed left the body at the moment of death. He believed these phenomena indicated the existence of a subtle body capable of exteriorization during life as well as at the moment of death. I present Bozzano's ideas in the context of his career as a psychical researcher and of previous discussions of the topic found in the early literature of Spiritualism and psychical research. Although some contemporary students of OBEs and NDEs still speculate on the relationship of these phenomena to the concept of survival of death, Bozzano's work is not widely cited today and few researchers have followed up his method. Nonetheless, his work is of historical interest, reminding us of areas and phenomena that deserve further study.
\end{abstract}

KEY WORDS: Ernesto Bozzano, bilocation, out-of-body experiences, deathbed phenomena, apparitions of the living, survival of death.

Italian psychical researcher Ernesto Bozzano (1862-1943) was an important defender of the concept of survival of death through the study of the phenomena of parapsychology. Part of this work centered on the phenomena of "bilocation," a term he used to refer to the

Carlos S. Alvarado, Ph.D., is Assistant Professor of Research in Psychiatry at the University of Virginia. He wishes to thank Nancy L. Zingrone for useful suggestions for the improvement of this paper, Cecilia Magnanensi for several relevant references to Bozzano's work published in Italian, and Andreas Sommer for assistance with German references. Reprint requests should be addressed to Dr. Alvarado at the Division of Personality Studies, Department of Psychiatric Medicine, University of Virginia Health System, P.O. Box 800152, Charlottesville, VA 22908-0152; e-mail: csa3m@virginia.edu. 
exteriorization or projection of both consciousness and subtle bodies from the physical body. This term is usually used in the Christian literature to refer to instances in which saints are seen as an apparition in a location different from where their physical body is actually located (Gregorio, 2004). Bozzano's concept of bilocation included out-of-body experiences (OBEs), near-death experiences (NDEs), and other phenomena I will discuss later in this paper.

Although Bozzano was an active contributor to the Italian and French literatures on psychic phenomena from the turn of the century to the early $1940 \mathrm{~s}$, his writings on bilocation are generally forgotten today. This work does not appear in a number of comprehensive discussions of the topic of survival of death that include OBEs (Almeder, 1992; Braude, 2003; Fontana, 2005; Gauld, 1982; Roll, 1982). While Bozzano has been cited in some discussions about OBEs, these citations have been limited to his views about specific features of the phenomena (Alvarado, 1997, pp. 21-22; Irwin, 1985, p. 22). But Bozzano's actual work, that is, his particular approach to the analysis of bilocation, and his conceptualizations of this phenomena, have been neglected (for an exception see the brief discussion in Alvarado, 1989, p. 30). Such neglect may stem from a variety of reasons. Most of Bozzano's works appeared before 1940 and they were published mainly in Italian and French. Furthermore, many of Bozzano's methodological and conceptual assumptions may be questioned by contemporary academic researchers who study the relevant phenomena, as I will discuss later.

However, Bozzano's work deserves to be better known not only because of its place in the history of the subject, but also to assess its relevance today. In order to contribute to the dissemination of his ideas about bilocation, I reprint here one of his later discussions on the subject. This will be preceded by a general discussion of Bozzano and the context of his ideas, that is, the literature discussing the belief that consciousness can leave the body both during life and at death. In addition, after presenting the excerpt of Bozzano's writings, I will briefly discuss his work in the context of modern developments.

\section{Bozzano and Psychical Research}

By the early 1890 s, when Bozzano became interested in psychic phenomena, both Spiritualism and psychical research had developed a considerable literature (Inglis, 1992). Although there had been much 
interest in telepathy (Luckhurst, 2002), many of the efforts of psychical researchers focused on the empirical study of phenomena that some believed indicated the possibility of survival after bodily death. This approach was very influential on the research agenda of a variety of psychical researchers, including those of the London-based Society for Psychical Research, founded in 1882 (Alvarado, 2003; Gauld, 1968). Studies of this type included research into haunted houses, apparitions, and the performances of mediums, that is, individuals who presumably were able to manifest the influence of deceased persons. The phenomena of mediumship included visions, speaking and writing, and such physical effects as telekinesis (movements of objects without contact) and materializations (appearances of body parts or whole bodies) in the séance room.

Bozzano began to study psychic phenomena in 1891 and soon gained an international reputation for a career devoted to establishing the existence of spirit (Alvarado, 1987a, 2000a; Bozzano, 1924; Iannuzzo, 1983; Ravaldini, 1993; Siegel and Hirschman, 1983). In looking back on his work, some said Bozzano was the dean of Italian spiritists and psychical researchers (Fodor, 1933/1966, p. 36). His writings were hailed as among the classics of modern Spiritualism (Meyer, 1928, p. 439).

By his own admission, Bozzano had a materialistic approach to life and intellectual concerns, but his reading of the psychical research literature and later experiences with mediums convinced him that the phenomena were real and that many of them indicated that humankind survived bodily death (Bozzano, 1924). This belief, as well as his experiences with the influential Italian physical medium Eusapia Palladino (1854-1918) (Alvarado, 1993), were expressed in his book Ipotesi Spiritica e Teoria Scientifiche (Bozzano, 1903). Throughout the years Bozzano became known for many reasons, but I will focus here on those I consider to be the most important.

First, Bozzano produced highly polemical writings countering antisurvival speculations. This included, but was not limited to, criticisms of French physiologist Charles Richet (1850-1935) and psychical researcher and popularizer of science René Sudre (18901968) (Bozzano, 1923b, 1926). His criticism of Sudre was published in book form, in which Bozzano replied to Sudre's attempts in his textbook Introduction à la Métapsychique Humaine (1926) to explain survival-related phenomena in purely psychological terms or as the parapsychological powers of the living.

Second, Bozzano argued that psychic phenomena showed that human beings had a nonphysical component. For example, he considered 
telepathy to be "basically a manifestation of a psychic or spiritual nature" (Bozzano, 1933, p. 148; this, and other translations, are mine) and a faculty "independent of the psychophysiological functions of the cerebral organ" (p. 149). Similarly, in his book Dei Fenomeni di Telestesia Bozzano argued that telesthesia (or clairvoyance) was a spiritual, nonphysical faculty (Bozzano, 1942, pp. 172-173). This nonphysicality was made evident in his discussions of phenomena that indicated survival of death such as haunted houses and deathbed visions (Bozzano, 1919/1925c, 1923c). In fact, Bozzano believed that survival of death was proved beyond a reasonable doubt. In his view, the investigations conducted in different areas of psychical research without prejudice and following a scientific approach "all converge ... in the experimental demonstration of the existence and the survival of the soul" (Bozzano, 1923c, p. 260).

Third, in an argument closely related to the previous point, Bozzano actively defended the view that supernormal subconscious functions were independent of biological evolution. In an early article he stated that the powers of the subconscious were not affected by natural selection. Furthermore, he affirmed in the article (following Myers, 1903) that these powers belonged to a spiritual realm and that their purpose was to be used after bodily death (Bozzano, 1906, p. 561; for later discussions of evolution see Bozzano, 1923a, ca. 1938).

Fourth, and also related to the second and third points, Bozzano (1926, ca. 1938) believed that survival of death was proved by the combined consideration of phenomena produced by the dead and by the living, the latter of which Bozzano referred as "animism." Although traditionally the word "animism" is used to refer to the belief that objects and other aspects of nature have a spiritual essence, Bozzano here followed Alexander Aksakof (1890/ca. 1906) in using the term to denote the psychic powers of the living. This position differed from that of those who saw the psychic powers of the living as mere explanations for survival phenomena (Richet, 1924; Sudre, 1926). Because such animistic phenomena as telepathy and clairvoyance were not considered to have physical explanations or to be shaped by biological evolution, Bozzano saw them as demonstrating the existence of a nonphysical component during life. Instead of using animistic phenomena to explain spiritistic phenomena, Bozzano argued that they should be seen as the complement of discarnate influence:

Both are indispensable for the purpose and cannot be separated, since both are the effects of a single cause; and this cause is the 


\begin{abstract}
human spirit, which, when it manifests in transient flashes during "incarnate" existence, determines animistic phenomena, and when it manifests in a "discarnate" condition in the world of the living, determines spiritistic phenomena" (ca. 1938, pp. viii-ix).
\end{abstract}

Fifth, Bozzano published many studies of specific topics or types of phenomena in which he brought together many cases from both the spiritualistic and psychical research literatures. Among these were how symbolism appears in such phenomena as extrasensory perception (ESP) and apparitions (Bozzano, 1907); the different ways in which thought and will can create reality, as seen in such physical phenomena as materializations and thought-photographic effects (Bozzano, 1926-1927/1929); and the occurrence and importance of psychic phenomena in so-called primitive people (Bozzano, 1927). Furthermore, Bozzano conducted many studies of the manifestation and gradation of features in a variety of specific phenomena such as haunted houses, deathbed phenomena, mediumistic communication from the living, cases of "transfiguration" in which the medium's face was altered, clairvoyance, and "transcendental" music (music heard at deathbeds or produced by mediums), and mediumistic communications describing the experience of death (Bozzano, 1919/1925c; 1923c, $1925 \mathrm{~b}, 1934 \mathrm{~b}, 1942,1943 / 1982,1952$ ).

In this work, Bozzano arranged cases in terms of types and tried to establish continuities between the different types to support his spiritualistic interpretations. In his analyses, Bozzano emphasized the importance of the principle of convergence of proof. This referred to the confluence of different types and features of the phenomena to support his survival interpretations. For example, in his book Phénomènes Psychiques au Moment de la Mort, Bozzano (1923c) used a variety of deathbed manifestations, including visions, movement of objects, and music heard at deathbeds, to defend the concept of discarnate agency. Some specific characteristics of the cases, such as collective percipience, were also discussed to support the point.

In his arguments, Bozzano characteristically emphasized that his conclusions were logical, being strictly derived from the analysis of facts. For example, in a paper on telepathy, he referred to the "indubitable existence" of facts "demonstrated" by his "comparative analyses of the facts" (Bozzano, 1933, p. 156). He took a similar approach in the excerpt on bilocation phenomena reprinted below.

Bozzano's numerous publications were used as a convenient reference for illustrative purposes even by authors who did not follow 
his conclusions. The latter was particularly true among writers outside of the Anglo-American tradition (Richet, 1922; Sudre, 1926). Furthermore, a widely used reference work, Nandor Fodor's (1933/ 1966) Encyclopaedia of Psychic Science, mentioned Bozzano repeatedly in many entries, including those about hauntings (p. 165), premonitions (p. 299), symbolism (p. 374), and xenoglossy (p. 410). However, Bozzano's influence regarding ideas of nonphysicality and survival was limited, for the most part, to those individuals who were already convinced of those interpretations. In fact, his books were frequently criticized by others who raised questions about evidentiality in the cases he discussed and about his interpretation (De Vesme, 1934; Driesch, 1932/1933, pp. 34, 155; Saltmarsh, 1938). One of his strongest critics pointed out that Bozzano confused facts and their interpretation, and that he had a tendency to assume dogmatically that he had reached the truth through analyses of cases that did not, in fact, provide all the necessary information for such conclusions (De Vesme, 1935).

\section{The Immediate Context for Bozzano's Ideas of Bilocation}

Before presenting an excerpt of Bozzano's writing on bilocation, I want to emphasize the importance of the literature that influenced him. Bozzano was extremely well read both in the publications that preceded him and in those contemporary to his work. Some of what I mention below was cited by Bozzano and it is likely that he was familiar with the rest of this literature. Leaving aside discussions of concepts and cases related to ideas about the separation of the soul, spirit, or subtle body from the physical body published before the $19^{\text {th }}$ century (Mead, 1919; Poortman, 1954/1978; Zaleski, 1987), I will discuss briefly the literature that provided a context for Bozzano's later ideas. Readers interested in more details about some of these materials should consult my previous reviews (Alvarado, 1980, 1989) and those of Susan Blackmore (1982), and Harvey Irwin (1985).

In addition to conventional religious views about the spirit, the soul, and its destiny (Alger, 1878), during the $19^{\text {th }}$ century several movements promoted the existence of some component of human beings capable of slightly detaching from or completely leaving the physical body, and thus producing a variety of psychic phenomena. One 
of these movements was mesmerism. In the view of an early mesmerist, the somnambulist (or "magnetized" individual) could show clairvoyance because the soul was temporarily detached from the usual sensory pathways and could receive impressions directly from a subtle principle that acted as an intermediary between the physical body and the soul (Chardel, 1818, p. 37). Others referred to this principle as a semimaterial body made of nervous fluid (Charpignon, 1851, p. 76).

Some of the old mesmerizers used to "send" their magnetized subjects to distant locations to test their clairvoyance, a phenomenon that came to be called "traveling clairvoyance." While some subjects only reported images of distant locations, others seemed to feel that they were actually in that location. In a description of what seemed to be an $\mathrm{OBE}$ in a magnetized individual, one author wrote:

it appeared, as if her mind partially left her body, to go to the place sought; ... From these distant places, the mind seemed to come fully back ... But this coming back was attended with ... much prostration, and ... alarming palpitation of the heart ...." (Haddock, 1851, p. 107).

Later magnetic work included that of French researchers Albert de Rochas (1837-1914) and Hector Durville (1849-1923). Their magnetized subjects claimed they could see their own doubles or the doubles of other subjects (De Rochas, 1895; Durville, 1909). Furthermore, Durville (1909) presented pictures of the outlines of his subject's exteriorized "phantoms" and recorded observations of physical phenomena produced by them at his command.

Some reported that communications received through mediums referred to a fluidic body called the "perispirit" that allowed the immaterial spirit to use the physical body and to produce all kinds of phenomena, such as movement of tables and visible apparitions (Kardec, 1863). The spirit was reportedly able to leave the physical body in certain conditions such as sleep or trance, although

during life the spirit is never completely separated from the body. The Spirits, similar to some seeing mediums, recognize the Spirit of a living person through a luminous trail coming from his body, a phenomenon that does not take place when the body is dead .... (Kardec, 1863, p. 146)

Similarly, it was argued that a person "may in the present life detach his soul, in a greater or less degree, from its corporeal organization" (Jung-Stilling, 1808/1851, p. 229).

Apparitions of the living were explained by many through the concept of a "double," or subtle replica of the human body housed 
inside it but able to leave the body in certain conditions. Examples of this idea are available in the work of such authors as Adolphe D'Assier (1883/1887), Annie Besant (n.d.), Louis-Sophrone Fugairon (1907), and Sylvan Muldoon and Hereward Carrington (1929). In addition, many of these were cases in which the person who appeared was not conscious of leaving the body, such as those in which the apparition coincided with crises brought on by illness, accidents, or being neardeath. These are the cases that formed the subject matter of a study that, to this day, is considered one of the central classics of early psychical research, Phantasms of the Living (Gurney, Myers and Podmore, 1886). Although the main thesis of the book was not the projection of a double, but the idea that these apparitions were hallucinations caused by telepathy, one of the authors of the book disagreed (Myers, 1886). As he elaborated in a later publication, some people had a "special idiosyncrasy which tends to make the phantasm of a person easily perceptible; the breaking loose of a psychical element, definable mainly by its power of producing a phantasm" (Myers, 1903, Vol. 1, p. xx).

In addition to apparitions, there was much speculation on the role of the double in explaining materialization phenomena. Thus, in one case it was argued that the materialization of a whole body was "not an independent spirit, but the spirit, or 'double' of the medium ...." (Anonymous, 1873, p. 452). The concept was also used later with medium Eusapia Palladino to account for phenomena such as the imprints of faces and hands on clay (De Rochas, 1897, p. 25). Other ideas about subtle bodies came from a variety of occult teachings (Papus, 1900). The movement of Theosophy was particularly influential, in that it emphasized a variety of subtle bodies with different properties and functions (Deveney, 1997). As one representative of this movement wrote, some people could project their "astral body" (Judge, 1893, Chapter 5).

Outside of Theosophy, there were also published cases of individuals claiming to have had the experience of being out of the body. Some consisted of a single or a few experiences (Committee of the London Dialectical Society, 1871, pp. 162-163; Crowe, 1848, Vol. 1, pp. 178179; Durville, 1909, pp. 82-89; Funk, 1907, pp. 181-184). For example, in one case the experiencer was studying for a medical exam and felt unable to move. He wrote:

I suddenly seemed to divide into two distinct beings .... One of these beings remained motionless on the sofa; the other could move some 
little distance, and could actually look at the motionless body on the sofa. There existed between these two "beings" an elastic force which prevented the one from severing its connection with the other. At will I could make the second "being" lie on the floor, or move some distance about the room. As the distance between the two beings became greater, so did the elastic force seem to become more powerful. A limit was soon reached at which no effort of will could effect a further severance. This limit was about two yards. When this limit was reached, I could feel resistance to the separating efforts in both "beings" ... I resisted the feeling of fusion. It could be prevented at will. Eventually, with a curiosity to know "what was going to happen next," I allowed it to proceed. The two beings then rapidly united again .... (Simons, 1894, p. 288)

There were also accounts of recurrent OBEs published in such books as The Beginnings of Seership (Turvey, ca. 1911) and My Travels in the Spirit World (Larsen, 1927), and in articles (Fox, 1920). None of these was as detailed about the features of the experiences as Muldoon's discussions in The Projection of the Astral Body (Muldoon and Carrington, 1929). This book was and remains influential because of its detailed discussion of induction methods and of specific "astral" phenomena. Another influential work along these lines was Méthode de Dédoublement Personnel, by French occultist Charles Lancelin (1852-1941). He discussed such projection methods as the training of the will and autosuggestion, as well as the importance of a variety of physical conditions to successfully project the astral body such as ambient temperature, bodily position, and mood (Lancelin, 1913/1986).

Furthermore, there were NDE accounts as well (Myers, 1892, pp. $180-186,195-200$ ). One of them was the widely cited case of physician A. S. Wiltse. After he experienced some rocking motions he wrote:

I felt and heard ... the snapping of innumerable small cords .... I began slowly to retreat from the feet, toward the head .... I passed around the brain as if I were hollow, compressing it and its membranes, slightly, on all sides, toward the centre and peeped out between the sutures of the skull, emerging like the flattened edges of a bag of membranes. I recollect distinctly how I appeared to myself something like a jelly fish as regards colour and form .... As I emerged from the head I floated up and down and laterally like a soap-bubble attached to the bowl of a pipe until I at last broke loose from the body and fell lightly to the floor .... I seemed to be translucent, of a bluish cast and perfectly naked .... (Myers, 1892, p. 181)

In addition to apparitions of the living, OBEs, and NDEs, Spiritualism always delivered the message that death was a transition to another world. This idea came frequently through mediumistic 
communications received from supposed spirits. Chemist and physician Robert Hare (1781-1858) recorded mediumistic messages in his book Experimental Investigations of the Spirit Manifestations (1855), in which communicators described "spiritual birth," descriptions of the spirit leaving the physical body at death.

Another interesting line of discussion characterized death as a permanent $\mathrm{OBE}$. In one such case apparently clairvoyant individuals observed emanations from the body at death, a description of which appears in the excerpt reprinted below. Clairvoyant and "inspired" speaker Andrew Jackson Davis (1826-1910) described the process as follows:

The clairvoyant sees right over the head ... a magnetic halo ... in appearance golden, and throbbing .... The person has ceased to breathe, the pulse is still, and the emanation is elongated and fashioned in the outline of the human form! ... The head of the person is internally throbbing .... The golden emanation ... is connected with the brain by a very fine life-thread. Now the body of the emanation ascends. Then appears something white and shining, like a human head; next, in a very few moments, a faint outline of the face divine; then the fair neck and beautiful shoulders; then, in rapid succession, come all parts of the new body down to the feet-a bright, shining image, a little smaller than this physical body, but a perfect prototype or reproduction.... The fine life-thread continues attached to the old brain .... When this thread snaps, the spiritual body is free! And prepared to accompany its guardians to the Summer-Land (Davis, 1868, pp. 15-16).

In one of these cases medium William Stainton Moses (1839-1892) reported that he observed a luminous aura around a dying individual (Anonymous, 1887/1904). In another case the husband of a dying woman observed for several hours mists and spirits around his wife, as well as the departure of her spirit, which was connected to the physical body through a cord (Anonymous, 1908, pp. 309-310). None of the other people present saw any of this. Such accounts of death may have inspired allegedly successful attempts to photograph and weigh the departure of some component of the human body at death (Baraduc, 1908; MacDougall, 1907). But similar claims of instrumental detection were also found in the literature in which occasional and usually controversial photographs were taken that were said to depict the double of living persons (Oxon, 1876).

Many believed that these phenomena supported the view that "something" could be exteriorized from the body. This "something" was believed to be able to carry consciousness on occasion and to separate 
from the body permanently at death (Mattiesen, 1931, 1936-1939, Vol. 2, pp. 296-411). However, not everyone shared these views. English psychical researcher Edmund Gurney (1847-1888) believed that some apparitions of the living in which the persons who appeared felt they were at the location where they were seen could be explained by telepathy between the two parties (Gurney, Myers, and Podmore, 1886, Vol. 2, Chapter 17). Gurney also described nonveridical spontaneous sensations of feeling oneself out of the body as a hallucination (Gurney, Myers, and Podmore, 1886, Vol. 1, p. 288, footnote). This interpretation was shared by later writers whom Bozzano cited in his publications (Osty, 1930). Several others did not accept the idea that objective doubles could be projected from the body (Richet, 1922; Sudre, 1926).

\section{Bozzano on Bilocation}

Bozzano defined bilocation as a conglomerate of manifestations showing a gradation from phenomena of the living to those taking place during the dying process that, in his view, showed the existence of a subtle body and indicated the potential to survive death. Somewhat similar approaches may be found in the writings of Gabriel Delanne (1909), William Harrison (1879), and Frederic W. H. Myers (1903). Bozzano discussed the topic in many publications (1923c, pp. $102-103$; 1926, Chapter 10 ; 1933, pp. 151-152; 1934a; ca. 1938, Chapter 4 ; 1942, pp. 155-156) and commented on the similarity between descriptions of the process of death given by mediumistic communicators and by clairvoyants (Bozzano, 1952). Bozzano's main discussion on the subject consisted of a multipart paper (Bozzano, 1911) and an expansion of this paper into a book, the French translation of which was entitled Les Phénomènes de Bilocation (Bozzano, 1934/1937).

In this book, Bozzano claimed that bilocation phenomena were of "decisive importance" to the argument for survival of death because they proved the existence of an "etheric body" within the somatic body that may exit the physical body during its life (Bozzano, 1934/1937, p. 8). He discussed the topic using four groups of cases. The first group included phantom limb sensations experienced by amputees and the sensations of doubling reported by hemiplegics. Not convinced of the validity of conventional neurological explanations for these phenomena, Bozzano believed instead that the sensations in question were 
explained by a fluidic body and that they represented the initial stage of bilocation phenomena.

The second group of cases were those of visions of the self while consciousness remained in the physical body (autoscopy). Bozzano accepted that some of these cases had a pathological component. But overall, he saw them as the transition between being in the body and getting out of it. This was particularly true of a small number of cases in which consciousness seemed to shift between the physical and the autoscopic body.

The third group of cases consisted of those in which consciousness was felt to be definitively separated from the physical body (OBEs and NDEs). These cases took place mainly "during absolute rest of the body" (Bozzano, 1934/1937, p. 41). Bozzano emphasized cases in which the person had been to a place far from the body and obtained information about events taking place at that distant location.

Finally, in the last group of cases Bozzano included those accounts in which the phantom of the living person was perceived by a third party. Not counting an NDE case that was not perceived by anyone else other than the experiencer, the chapter included eight accounts of apparitions of the living and 13 accounts of emanations from the body of dying individuals. The latter referred to mists or cloud-like forms, luminous manifestations, and the shape of the dying individual.

Bozzano admitted that in some cases it was difficult to distinguish between the projection of a double and a telepathic hallucination. Nonetheless, he argued that the projection explanation was a better one in many cases, particularly in those cases in which the phenomenon was perceived collectively. Observations made around the dying individuals were particularly impressive to Bozzano, who considered them to be an "embryonary or rudimentary" doubling representing the "initial phase of 'deathbed bilocation' phenomena" (Bozzano, 1934/1937, p. 120). This initial stage was the exteriorization of fluid subtle energies or matter in a diffuse state, a process that ended with the formation or the condensation of the whole etheric body. Furthermore, Bozzano believed that the deathbed vision of the dying themselves, as well as apparitions of the dead, complemented bilocation and represented the functioning of consciousness after separation from the body. However, those phenomena received only a brief mention at the end of the book.

Following his well-known approach to case analyses, Bozzano (1934/ 1937 , p. 172) argued that his classification and analysis of cases put emphasis on "legitimate and conclusive" evidence he obtained through 
"comparative analysis and the convergence of proofs." Each of the above mentioned phenomena was seen to converge on the conclusion of the existence of a fluidic body. The objective nature of this agent, Bozzano believed, was evident because of his use of "procedures of comparative analysis with hundreds of facts of the same genre ... which represent all the gradations that this phenomenology shows ...." (Bozzano, 1934/1937, p. 172). Starting with sensations within the body, the cases progressed to seeing oneself from the physical body, to having consciousness projected out-of-the-body into a phantom body, and finally to what seemed to Bozzano to be a permanent projection from the body. The latter was the only group of cases that did not depend on the testimony of the experiencer.

In the final pages of his monograph Bozzano stated that the acceptance of an etheric body as an explanation for the above mentioned phenomena implicated the existence of an etheric brain. Furthermore, this conclusion showed the existence of the spirit, an entity that ruled the mind using the body to manifest itself but independent of it (Bozzano, 1934/1937, p. 175).

The excerpts reprinted below consist of parts of Chapter Four of Bozzano's Discarnate Influence in Human Life (pp. 101-149), published around 1938 (the book was also published in Italian: Bozzano, 1938/1967). The organizing committee of the International Spiritualist Congress, held at Glasgow in 1937, presented an invitation to Bozzano to write this book, asking him to be the Honorary Vice-President of the Congress and to summarize his many years' work on the topic "Animism or Spiritism: Which Explains the Facts?" (Bozzano, ca. 1938, p. vii). The excerpts, with my comments added in brackets, follow:

The generic appellation "Phenomena of Bilocation" is used to designate the various ways in which the mysterious occurrence of "exteriorization of the double" takes place in the bodily organism. These phenomena are of fundamental importance for metapsychical science, since they serve to show that animistic manifestations, although connected with the functions of the psycho-physical organism of the living, have their origin in something qualitatively different from the organism itself. Hence they assume a definite theoretical value for the experimental demonstration of the survival of the human spirit. In other words: the phenomena of bilocation demonstrate that within the "somatic body" there exists an indwelling "etheric body," which in rare circumstances of weakening of vitality in the individual (physiological sleep, hypnotic sleep, mediumistic trance, ecstasy, swooning, narcosis, coma) is able to 
release itself temporarily from the "somatic body" during incarnate existence. The inevitable inference follows that if the etheric body is able to separate temporarily from the somatic body, preserving its consciousness intact, we must end by recognizing that when it separates definitively at the crisis of death, the individualized spirit will continue to exist in an appropriate environment. This is equivalent to admitting that the fact of the immanent existence in the somatic body of an etheric body, and consequently of an etheric brain, shows that the seat of consciousness, intelligence, memory and supernormal sense faculties, is the etheric body, which is the sublimated and immaterial garment of the discarnate spirit.

In 1910 I published a long monograph on the phenomena under examination [the actual year was 1911]; but as facts of this nature continued to accumulate in great numbers, I decided recently to publish a second edition, double the size of the first. Thus I am in a position to discuss this important question with full knowledge of the subject. In the work alluded to I start from the so-called phenomena of "sensations of wholeness in the amputated," where, at times, the sense of the wholeness of the missing limb is so real that even if the individual's attention be distracted, he still feels the sensation that the missing limb would have felt had it been there. And that a limb in a fluidic state really exists there may be concluded from the fact that "clairvoyant sensitives" affirm that they see it. In this connection I recalled the interesting case narrated by Dr. Kerner in his famous book, The Seeress of Prevost, in which the seeress in question, when she met a person who had lost a limb, continued to see the missing limb joined to the body in a fluidic form .... [German poet and physician Justinus Kerner (1786-1862) recorded the trances and psychic phenomena of Frederica Hauffe (1801-1829) (Kerner, 1845). For a discussion of the experiences of amputees as a function of the spiritist concept of the perispirit see D'Assier, 1883/1887, pp. 103104, and Bouvery, 1897, pp. 44-47].

There is ... no doubt that the phenomena of "sensations of wholeness in the amputated," concur admirably to demonstrate the existence of an etheric body immanent in the somatic body. Hence the importance they assume for the scientific demonstration of the existence and survival of the human spirit.

I discussed in my monograph, after cases of the above nature, instances of "incipient bilocation" of those suffering from hemiplegia, who sometimes see, on the paralysed side, a longitudinal section of the phantasm of themselves, and affirm that it enjoys a completeness of sensation, a fact inexplicable by Dr. Sollier's "coenesthesic" hypothesis, since in those afflicted with hemiplegia, far from an exaggeration of the coenesthetic sense, the suppression of this sense exists [Paul Auguste Sollier (1861-1933) published an important book on autoscopy (Sollier, 1903)].

Next follows the cases of "autoscopic bilocation," in which the subject sees his own phantasm while preserving full consciousness .... I show that if the psychopathic hypothesis formulated by Dr. Sollier to 
explain these cases in their totality could be held legitimate before the advent of metapsychical investigation, it is now no longer so, since in the same manner as the investigations of telepathy demonstrate that not all hallucinations are fictitious, so the investigation of the phenomena of bilocation shows that not all episodes of autoscopy are psychopathic [The most important study of telepathy used to show that not all hallucinations were subjective was that of Gurney, Myers and Podmore (1886). Other influential works included the studies of Aksakof (1890/ca. 1906), Delanne (1909), and Flammarion (1900)].

I then passed on to the analysis of the cases in which consciousness is transferred to the phantasm, which sees before it its own unconscious body. These are very interesting cases, in which the supernormal sensory faculties emerge.

... The exteriorization of the double takes place during normal sleep, hypnotic sleep, swooning, narcosis and coma; and successively the cases in which the liberated phantasm of a sleeping living person is perceived by other persons; arriving finally at the cases in which the phenomenon of bilocation takes place on the deathbed. This last category is the most important of all ... . Lastly episodes were cited in which the watchers observed the phenomenon in all phases of its evolution, to the perfect reproduction of a fluidic simulacrum of the somatic body of the dying, an animated, living simulacrum, assisted by apparitions of the dead, who apparently attend at deathbeds for that purpose.

With regard to these last important phenomena of bilocation at a deathbed, I insisted on the vitally important fact that all clairvoyants, no matter to what peoples they belong - civilized, barbarous or savage - describe the development of the phenomena in substantially identical terms; which shows that the clairvoyants describe a positively objective phenomenon; otherwise it would be impossible that all should agree in enumerating the same phases of the phenomenon, wherein are contained particulars so new and unthought of, that by the hallucinatory hypothesis they could certainly not be produced identically in all the hallucinated ....

As has already been stated, the phenomena of bilocation in general, but especially those in which the consciousness is transferred to the phantasm, occur in many gradations during states of weakening of vitality in individuals, such as physiological sleep and that induced by anaesthetics, the somnambulistic-hypnotic phases, swooning, coma, the crises of convalescence, nervous exhaustion, or moral depression. They rarely occur in physiologically and psychically normal conditions; in such cases they take place in circumstances of absolute bodily repose, more especially in the period that precedes or follows sleep. In the last circumstance the sense of bilocation is somewhat vague, undecided, and of very short duration.

One of the most notable characteristics of the cases in question would seem to consist of the fact that in cases of the appearance at a distance of the bilocated phantasm, various incidents of veridical 
perception of distant things and situations ... almost always occur; these are sometimes observed also in cases in which the double does not go far from its body.

Psychologically speaking, the fact of feeling oneself existing personally, in the fullness of sentiment and conscious faculties, outside the body and contemplating the body, is a fact worthy of profound meditation. It is a feeling difficult to reduce to elucidatory formulas derived from the psychology of the schools, inasmuch as this phenomenon differs radically from those of "autoscopy," in which the conscious self remains in the organism and sees its own phantasm at a distance, a phenomenon analogous to others cited in works on mental pathology, and reducible to a pure and simple case of hallucination. Here, on the contrary, we find the inverse phenomenon which in this particular case leaves no opening for the hallucinatory hypothesis, considering that from the psychological point of view an insuperable abyss exists between the sensation of seeing one's own double and that of finding oneself consciously out of the body, and contemplating the body....

... I will relate only one episode in which the bilocated phantasm begins to exercise supernormal sensory faculties. My friend, the engineer Giuseppe Costa ... narrates the following episode which happened to himself [in a book describing his psychic experiences and opinions (Costa, 1923)]: “... . I had been obliged to yield, completely exhausted, to an imperative need of repose, and had thrown myself on the bed, fainting rather than asleep .... An unconscious movement of my arm, probably, overturned the lamp ... and instead of going out, it gave off a dense smoke which filled the room with a black cloud of heavy, acrid gas .... I had the clear and precise sensation of finding myself with only my thinking personality, in the middle of the room, completely separated from my body, which continued to lie in bed .... I saw my body perfectly recognizable in all its details, the profile, the figure, but with the clusters of veins and nerves vibrating like a swarm of luminous living atoms .... I wanted ... to pick up the lamp and open the window, but it was a material act that I could not accomplish .... Then I thought of my mother, who was sleeping in the next room. I saw her clearly through the dividing partition, quietly asleep in her bed .... It seemed to me that no effort of any kind was needed to cause her to approach my body. I saw her get hurriedly out of bed, run to the window and open it, as if carrying out my last thought before calling her; then leave her room, walk along the corridor, enter my room and approach my body grippingly and with staring eyes .... My mother, questioned by me soon after the event, confirmed the fact that she had first opened the window as if she felt herself suffocating, before coming to my aid. Now the fact of my having seen this act of hers through the wall, while lying inanimate on the bed, entirely excludes the hypothesis of hallucination and nightmare during sleep in normal physiological circumstances" ... . [Costa] ... succeeded in telepathing his thought to his mother, so as to wake her and bring her to his aid, thus saving him from certain death .... 
I will ... pass on to relate some examples of another category, wherein are found the greatest number of cases of bilocation; it is also the most important because it deals with phenomena of "death-bed bilocation" which are observed by "sensitives," and often by persons who cannot be considered as such ... . I will narrate first an example taken from a group of cases in which the bilocation is of an incipient or rudimentary order and is observed collectively and successively by several persons; this last circumstance is of great evidential value as regards the objectivity of the phenomenon. I consider cases of this kind very instructive, since they represent the initial phase of the phenomena of "death-bed bilocation," in which can be observed the emergence from the physical body of fluid substance in a diffused state, which, after repeated fluctuations caused by partial reabsorption on the part of the organism (corresponding with the fluctuations of vitality in the sick person) ends by integrating into a "living and animated etheric body" as the supreme hour approaches [Such ideas about "fluids" should be seen in the context of speculations about the nature of subtle bodies, such as those in Baraduc (1893), Besant (n.d.), Durville (1909), Fugairon (1907), Kardec (1863), and Lancelin (1913/1986), and a variety of concepts of bodily forces meant to explain mediumistic phenomena, as seen in the writings of Crookes (1874), Geley (1924/1927), Schrenck-Notzing (1920/1925), and Sudre (1926); see also Alvarado (2005)].

It follows that cases of an incipient order are not less important than those in which the bilocation is complete, since they instruct us concerning the phases which determine the great phenomenon in the supreme hour of the final detachment of the etheric body ... . I take from Light ... an episode in which there were eight percipients [For the actual reference see Monk (1922). Light, a British spiritualistic journal, started publication in 1881]. Miss Dorothy Monk sent ... the following account of what took place at her mother's death-bed, on January $2^{\text {nd }}, 1922$.

"After a long illness, terminating with gastric influenza, mother died of heart failure .... All through the night our family, consisting of father, a brother, five sisters and myself, watched by her ... . During the afternoon we saw bright blue lights, sometimes near her and sometimes about the room. We could only see them for a second or two, and usually only one or two of us at a time. I watched carefully, and three times out of four when I saw one near her she stirred and endeavoured to speak, but was past it by this time. At dusk that afternoon as she lay perfectly quiet, I and three sisters all at once noticed a pale-blue mauve haze all over her as she lay. We watched it and very gradually it deepened in colour until it became a deep purple, so thick that it almost blotted out her features from view, and spread all in the folds of the bed-clothes like a purple fog. Once or twice she feebly moved and the colours travelled with them. We thought it very wonderful, so called the two remaining sisters to see if they could see it too, and they could. At this time our sister saw a grey smoke-like object pass between two chairs; it was about three feet high and just glided away 
from the bed. I was sitting there, but did not see it. As we watched, very gradually patches of bright yellow light, like sunlight, appeared on the pillow; one at the left side of her head was particularly bright sometimes, and then would slowly dim and once more become bright again. Mother's old friend was also in the room during this time, but she neither saw the purple mist around mother nor the blue lights, and said that our eyes were tired with watching, and that we were overwrought. We drew her attention to this very bright patch on the pillow, and she saw it, but said it was the reflection of the fire or gaslight. We screened both, and she then went round the room and moved pictures and photograph frames and tilted the mirror, but without making any difference to the light. At last she came and put her hands directly over it, but without shading it in any degree; after that she sat down without saying a word.

"Early in the evening I saw my eldest sister, and the other sister who saw the grey object before, both turn and look at the same time to the place where it had appeared, and they saw it once more; again I did not see it, but they both did, and both agreed as to the description. The sister who first saw it about this time also saw a large blue globelike light resting on mother's head, but none of the rest of us could see it. She explained that the inside appeared all moving and gradually it turned to deep purple and faded out.

"About seven o'clock that evening mother's lips parted and from that time we gradually saw a thick white mist collect above her head and spread across the head of the bed .... It came from the top of her head, but collected more thickly to the opposite side of the bed to which she was lying. It hung like a cloud of white steam, sometimes so thick we could scarcely see the bed-rails, but continually it was varying although it moved so slowly as to be scarcely perceptible. I and my five sisters were still with her and all saw it distinctly, also my brother and one brother-in-law. The blue lights continued about the room, also tiny flashes of yellow, like sparks, appeared sometimes. All this time mother's lower jaw gradually fell a little. For some hours we saw little difference except that a halo of pale yellow light rays came round her head; they were about seven in number; they varied in length from twelve to twenty inches at different times. By midnight everything had cleared off, but she did not die until 7:17 on the morning of January $2^{\text {nd }}$. At $6: 15$, one sister, who was resting in another room, heard a voice say: 'Another hour now ... another hour now;' it roused her, and she came back to mother who finally breathed her last one hour and two minutes later...."

No doubt can arise as to the objectivity of the complex manifestations which occurred, seeing that the final and most important phase of the manifestation was observed collectively by all those present.

The greater part of the other preceding and varied manifestations were also perceived collectively, though not always by all, and two of them were decidedly "elective." This would signify that the manifestations observed collectively were "ectoplasmic" emanations, and consequently visible to normal sight, while the apparition of a greyish 
smoky column perceptible to only two persons, and the luminous globe perceptible to only one person, were of a qualitatively different character, and consequently perceptible only to the eyes of "sensitives" [On selective perception of such phenomena see Gurney, Myers, and Podmore (1886, Vol. 2, pp. 221-223, 237-238, 619-622), and Anonymous (1908). Bozzano himself discussed selective perceptions in his writings about hauntings (1919/1925c, pp. 58 and 128-129), deathbed visions (1923c, p. 234), and music heard at deathbeds (1943/ 1982 , p. 117). "Ectoplasmic" refers to ectoplasm, a substance supposed to come out of the body of physical mediums to provide the basis for materializations (Geley, 1924/1927); see also Alvarado (2005). There are some reports that suggest that some of these supposed ectoplasmic structures are not always visible to everyone in a position to see them (Crookes, 1874, p. 92; Schrenck-Notzing, 1920/1925, pp. 175 and 181)]. It should accordingly be inferred that the phenomenon of the smoky column three feet high, and the other of a luminous globe over the head of the dying woman, must have represented the incipient exteriorization of the "etheric body" and the "mental body" of the invalid, not yet integrated and fused into one phantasm. I note in this connection that several cases are registered in my classification, in which, at the moment of death, the watchers saw a luminous globe issue from the head of the dying and rise rapidly, vanishing near the ceiling; while it is known that Dr. Baraduc succeeded in photographing an analogous apparition of a luminous globe at his wife's deathbed [French physician Hyppolyte Baraduc (1850-1909) took pictures of his wife as she lay in bed dying. The pictures show luminous globes of light (Baraduc, 1908). Baraduc was well known for his study of vital forces through a moving needle instrument (Baraduc, 1893) and photography (Baraduc, 1896)].

From another point of view, I observe that the brilliant bluish lights floating about the room, and often approaching the dying woman, who showed herself conscious of them by moving and trying to speak, were presumably of external origin; that is to say, what appeared as brilliant bluish lights to the sensitives watching, were for the dying woman the spirit forms of deceased relatives ....

A difficulty remains to be solved in that the fluidic exteriorization, after continuing to take place for five consecutive hours, dissolved instantly, while the invalid continued to live for another seven hours .... In that case it may be inferred that if the phenomenon dispersed seven hours before the invalid's death, this would be explained by the presumption that with the total emergence of the etheric body, the irradiation of vital fluids had ceased; hence the phenomenon vanished from normal sight, while the etheric body fully developed, hovering above the somatic body, remained there, perceptible only to the finer sight of sensitives and mediums [For a discussion of cases where the form of the dying person was actually seen close to or above the dying body see Crookall (1967); see also Anonymous (1908, pp. 309-310). Bozzano was familiar with a book by Joy Snell (1918), who had many visions of this sort during her career as a nurse]. 
However this may be, the perplexities inherent in the manner in which the phenomena of bilocation occur, have nothing in common with the problem depending on the objective reality of the phenomena themselves; and when all the various ways in which the phenomena under examination are classified, analysed and compared, beginning with that significant phenomenon of "sensations of wholeness in the amputated," and ending with the cases of clairvoyants who watch the reintegration and departure of a perfect etheric body, vitalized and animated, and also assisted by apparitions of the deceased who apparently attend at the deathbed for that purpose - when, I say, we are able to judge from the complex mass of facts, then the perplexities that remain to be solved lose all neutralizing theoretical value; since we are equally led to infer, on the basis of facts, that from henceforth we know enough about the phenomena of bilocation to conclude, without fear or error, that they alone suffice to demonstrate experimentally the existence and survival of the human spirit ... .

It is in fact evident that the existence of an etheric body immanent in the somatic body takes for granted the existence of an etheric brain within the somatic brain. This admission would clear up at once all the perplexities which have always held back physiologists from admitting the existence of a spirit surviving the death of the body, which perplexities are summed up in the indubitable fact of the existence of a psycho-physiological parallelism in the phenomena of thought, leading inexorably to the conclusion that thought is a function of the brain. There is no doubt that the physiologists were apparently right in concluding this; but they would not be so if the terms of the formidable problem were inverted by the experimental demonstration of the existence of an etheric brain within the somatic brain; in which case the latter would be merely the indispensable apparatus for the translation of the impressions that come to it from the outer world by means of the senses in the form of physical vibrations, into terms of psychic vibrations perceptible to the spirit immanent in the etheric brain ... . [There was of course a long tradition preceding Bozzano of discussions of the importance of the nervous system in human function and of the mind-body problem (Finger, 2000; Wright and Potter, 2000; Young, 1970). Three authors known to Bozzano, French philosopher Henri Bergson (1859-1941), American philosopher William James (1842-1910) and British psychical researcher Frederic W. H. Myers (1843-1901), postulated the action of a principle (mind, spirit) that was separate from the brain but used it to communicate through it (Bergson, 1908/1911; James, 1898; Myers, 1903)]. The existence of an etheric brain ... could explain a psycho-physiological enigma ... in connection with ... a German review containing a long article referring to certain cases observed during the Great War, in which soldiers who had had their brains torn up by shrapnel, with abundant loss of brain matter, recovered and kept their intellectual faculties intact. And the author of the article ended by citing ... the well-known case of a noncommissioned officer ... who after two years complained of persistent 
headache, which however did not prevent him from fulfilling the duties of his rank. He died suddenly, and an autopsy of his brain revealed the fact that an abscess of slow development had reduced the entire brain to a pulp of pus .... If the existence of an etheric brain, seat of the individual consciousness, were admitted, it would follow that the enigma of the "men who think without a brain" would be capable of ready explanation, since it is logically presumable that in given circumstances of "special fluidic synchronization" between the somatic brain and the etheric brain, the latter would be able temporarily to take the place of the somatic brain, doing without its own physical organ. In other words ... the only circumstance of fact absolutely necessary for the explanation of the disturbing mystery, is the recognition of the existence of an individual consciousness independent of the physical brain; and this is what we obtain by recognizing the existence of an etheric brain, seat of the integral subconscious personality and provided with supernormal faculties [French physician and psychical researcher Gustave Geley (18651924) reviewed cases of brain pathology like the ones mentioned by Bozzano and argued that they showed that the materialist hypothesis was erroneous (Geley, 1919/ca. 1920, pp. 78-83; see also Troude, 1920). Guépin (1915a, 1915b) reported an interesting case of this sort. Bozzano (1925a) himself discussed these topics in a previous essay].

\section{Discussion}

The interest Bozzano showed in the survival implications of OBEs and NDEs has continued to recent times (Becker, 1993; Fontana, 2005; Stevenson and Greyson, 1979). The survivalist position was clearly stated in a recent book in which it was suggested that the OBE

gives us a glimpse of what it may feel like to exist without a physical body and therefore of what it may feel like to survive death ... For if my consciousness can function outside and at a distance from my body, why not survive death without any body? (Grosso, 2004, p. 22)

However, as pointed out before, fairly recent discussions of the evidence for the concept of survival do not include reference to Bozzano's work, and more particularly, to his argument of the key importance of considering the above mentioned types of cases together, as opposed to dealing with each separate type in isolation (Almeder, 1992; Braude, 2003; Fontana, 2005; Gauld, 1982; Roll, 1982).

Few individuals have followed Bozzano's approach. P. T. Bret (1938) used published cases of apparitions of the living and OBEs to study different manifestations of the double, but did not follow Bozzano's 
survival model. There are similarities to Bozzano's approach in discussions of published cases by such authors as Raynor Johnson (1953) and Hilary Evans (2004), and especially in the projection and survival-oriented work of Muldoon and Carrington (1951) and Robert Crookall (1967). Crookall has come closer than anyone else to Bozzano's approach by bringing together several converging lines of evidence for projection phenomena from the old Spiritualist and psychical research literatures.

I mentioned earlier a few possible reasons for the neglect of Bozzano's work today, namely its publication date and the fact that most of his work did not appear in English. However, there are other possible reasons for this neglect as well. I believe many modern researchers may believe that Bozzano was too confident in his conclusions. If there is anything we have learned from the history of psychical research, it is to be skeptical of many claims of knowledge, particularly those that, like Bozzano's, are presented as "indubitable," "incontestable," and "irrefutable." Even assuming that Bozzano was right about bilocation, his style of presenting his conclusions may strike the modern reader as, at best, a belief and, at worst, a hasty use of the data at his disposal.

In psychical research, as in other areas of research, we need to distinguish between the data (which itself are not completely objective) and our interpretation of the data. So, when Bozzano assured us that phantom limb sensations were related to autoscopy, or that autoscopy involved the projection of the same double operating in an OBE, he was not stating a self-evident fact. Instead he was offering an interpretation of the cases he considered. In other words, the so-called "convergence of proof" is not as evident to others as it was to Bozzano.

Another obstacle to the acceptance of Bozzano's ideas, or even to the citation of his work today, is that modern research on spontaneous bilocation-related phenomena has changed since Bozzano's times. His use of different types of cases to reach conclusions by showing varieties and continuities in the phenomena was also used by others in the past in some classic works about apparitions and related phenomena (Gurney, Myers, and Podmore, 1886; Myers, 1903). This approach, however, is no longer the preferred method of study. Bozzano's use of cases to study types and gradations of phenomena with an emphasis on the principle of "convergence of proof" is no longer common. Recent work with OBEs and NDEs (Alvarado and Zingrone, 2003; Greyson, 2000 ) attests to the fact that studies of these phenomena are now conducted using questionnaires that offer the advantage that each 
study participant gets asked the same questions. Furthermore, most of the studies involve quantitative analyses that, in addition to assigning numerical values to the incidence and frequency of specific features of the phenomena, attempt to relate them to such factors as psychological variables. Thus, while Bozzano was trying to prove survival of death, contemporary researchers focus instead on relationships with other phenomena such as aftereffects (Alvarado and Zingrone, 2003), dissociation (Greyson, 2000) and body image (Murray and Fox, 2005).

Furthermore, part of the reason for the rejection of, or lack of interest in, Bozzano's approach is that the topic is conceptualized differently today. Authors such as Blackmore (1984, 1993), Irwin (2000), and Ronald Siegel (1980) see the OBE and the NDE as purely hallucinatory, a position defended as well for different reasons by several other modern researchers (Blanke, Landis, Spinelli, and Seeck, 2004; Blanke, Ortigue, Landis and Seeck, 2002; Brugger, 2002; Girard and Cheyne, 2004). The phantom limb sensation and autoscopy are not discussed today in the way Bozzano did. Most contemporary treatments of the phantom limb phenomena in the academic and scientific literatures assume neurological explanations unrelated to the notion of the projection of a subtle body (Brugger, 2003; Fraser, 2002; Halligan, 2002; McGonigle, Hännigen, Salenius, Hari, Frackowiak, and Frith, 2002; Melzack, 1989), although there are some exceptions in the popular literature (Sheldrake, 2003, pp. 281-284).

The same is true for autoscopy, which is generally considered a pathological condition (Dening and Berrios, 1994; Grotstein, 1983). Glen Gabbard and Stuart Twemlow (1984, pp. 56-58) and Irwin (1985, pp. 23-24) have tried to outline criteria to differentiate the OBE from autoscopy. Although autoscopy has been related to OBEs in recent times, such discussions do not proceed from the point of view of the projection of a double (Brugger, 2002). A recent paper suggested that both OBEs and autoscopy are caused by paroxysmal disorders of body perception and body schema (Blanke, Landis, Spinelli, and Seeck, 2004). Because these ideas reflect the reaction of the current scientific paradigm to the phenomena, it is unlikely that we will soon see empirical studies using Bozzano's approach. Furthermore, and particularly in the case of the phantom limb sensations, the phenomena do in fact seem consistent with neurological explanations, while remaining an anomaly for neurologists.

Taking a wider perspective, Bozzano's belief that the spirit acted through the brain, a well-known position in the history of the mind/ body problem (Wright and Potter, 2000), is not prevalent in today's 
scientific circles. With the exception of a few who have seen the mind as an independent causal agent acting through the nervous system (Beloff, 1994; Popper and Eccles, 1977; Thouless and Wiesner, 1947), most contemporary students of the mind seem to follow Roger Sperry (1993) in believing that consciousness "cannot exist apart from the functioning brain" (p. 879). This prevalent view, added to ideas of an etheric brain and the variety of bilocation phenomena discussed above, almost guarantee that most psychologists, psychiatrists, and neurologists (including some parapsychologists), cannot take Bozzano's proposal seriously.

Does this mean that the type of analyses Bozzano offered on bilocation are no longer useful today? While I believe we should not limit ourselves to Bozzano's approach, I would contend that his work still is useful. It reminds us of the complexity of the phenomena in question, a complexity that gets obscured today by the emphasis on studying the prevalence or frequency of experiences in relation to other variables, while giving little attention to the features of the experience itself (for a call to remedy this in relation to OBEs see Alvarado, 1997). Furthermore, Bozzano's work reminds us of that there are phenomena we are virtually ignoring today.

A case in point are observations such as those reported by Dorothy Monk (1922) and cited by Bozzano. Today very little work has been done with reports of luminous, misty, or other types of emanations from the physical body at the moment of death. Some exceptions include analyses of published cases by Crookall (1967) and by myself (Alvarado, 1987b), cases presented by Elizabeth McAdams (1984) and Carla Wills-Brandon (2000), and some general discussions of these phenomena (Ring, 1980, pp. 225-231). Unless one is prepared to dismiss such reports as hallucinations induced by the emotional context surrounding the deathbed, coupled with the personal beliefs of the experiencers, the similarities of features illustrate the potential pointed out by Bozzano. They remain a challenge for researchers, a challenge more difficult to meet than the scientific study of apparitions of the living, OBEs, and NDEs, if only because of the apparent rarity of these reports. On the other hand, perhaps what we need are new researchers who, inspired by such writers as Bozzano, eventually seek such cases.

Bozzano's work also reminds us of the existence of cases with features that can be verified. That is, there are experiences in which a person obtains verifiable information about events at the location to which he or she has "traveled," and in which apparitions of the 
traveler have been seen at the place the OBErs describe. Similar to the cases of observations around a death-bed, a small number of these apparitional cases are collectively perceived. Little attention has been given to these potentially important phenomena in modern times (for exceptions see Hart, 1954; Hart and associated collaborators, 1956; Ring and Lawrence, 1993).

To conclude, if Bozzano's work is to have an impact today, he needs to be rediscovered by those few scientists who are open to explanations other than the current hallucinatory and neurological conceptualizations of such phenomena as OBEs and NDEs. While it is unlikely that the inclusion of the phantom limb phenomena or autoscopy into the bilocation continuum will convince most, perhaps the further documentation of veridical OBEs and NDEs, as well as collective death-bed experiences could serve as a reminder that there are aspects of bilocation phenomena that we have yet to explain adequately within the context of the current scientific paradigm.

\section{References}

Aksakof, A. (ca. 1906). Animismo y espiritismo: Ensayo de un exámen critico de los fenómenos medianimicos [Animism and spiritism: Essay of a critical examination of mediumistic phenomena] (Marata, J. E., trans.). Barcelona: Carbonell y Esteva. (Original work published in German in 1890)

Alger, W. R. (1878). The destiny of the soul: A critical history of the doctrine of a future life (2 vols., $10^{\text {th }}$ ed.). New York, NY: W. J. Widdleton.

Almeder, R. (1992). Death and personal survival: The evidence for life after death. Lanham, MD: Rowman and Littlefield.

Alvarado, C. S. (1980). The physical detection of the astral body: An historical perspective. Theta, $8(2), 4-7$.

Alvarado, C. S. (1987a). The life and work of an Italian psychical researcher: A review of Ernesto Bozzano: La Vita e l'Opera by Giovanni Iannuzzo. Journal of the American Society for Psychical Research, 81, 37-47.

Alvarado, C. S. (1987b). Observations of luminous phenomena around the human body: A review. Journal of the Society for Psychical Research, 54, 38-60.

Alvarado, C. S. (1989). Trends in the study of out-of-body experiences: An overview of developments since the nineteenth century. Journal of Scientific Exploration, 3, 27-42.

Alvarado, C. S. (1993). Gifted subjects contributions to psychical research: The case of Eusapia Palladino. Journal of the Society for Psychical Research, 59, 269-292.

Alvarado, C. S. (1997). Mapping the characteristics of out-of-body experiences. Journal of the American Society for Psychical Research, 91, 13-30.

Alvarado, C. S. (2000a). Introduction to Ernesto Bozzano's analysis of hauntings and poltergeist cases. International Journal of Parapsychology, 11, 161-166.

Alvarado, C. S. (2000b). Out-of-body experiences. In Cardeña, E., Lynn, S. J., and Krippner, S. (Eds.), Varieties of anomalous experiences: Examining the scientific evidence (pp. 183-218). Washington, DC: American Psychological Association. 
Alvarado, C. S. (2003). The concept of survival of bodily death and the development of parapsychology. Journal of the Society for Psychical Research, 67, 65-95.

Alvarado, C. S. (2005). Concepts of force in early psychical research. Pesquisa Psi. Retrieved April 20, 2005 from http://www.pesquisapsi.com/artigo10.html

Alvarado, C. S., and Zingrone, N. L. (2003). Exploring the factors related to the aftereffects of out-of-body experiences. Journal of the Society for Psychical Research, 67, 161-183.

Anonymous. (1873, December 12). Spirit forms. The Spiritualist, pp. 451-454.

Anonymous. (1904). A vision of death. Light, 24, 167-168. (Original work published 1887)

Anonymous. (1908). Hallucinations experienced in connection with dying persons. Journal of the Society for Psychical Research, 13, 308-312.

Baraduc, H. (1893). La force vitale: Notre corps vital fluidique, sa formule biométrique [The vital force: Our vital fluidic body, its biometric formula]. Paris, France: G. Carré.

Baraduc, H. (1896). L'ame humaine: Ses mouvements, ses lumières et l'iconographie de l'invisible fluidique [The human soul: Its movements, its lights and the iconography of the invisible fluids]. Paris, France: Georges Carré.

Baraduc, H. (1908). Mes morts: Leurs manifestations, leurs influences, leurs telépathies [My dead: Their manifestations, their influences, their telepathy]. Paris, France: P. Leymarie.

Becker, C. B. (1993). Paranormal experience and survival of death. Albany, NY: State University of New York Press.

Beloff, J. (1994). Minds and machines: A radical dualist perspective. Journal of Consciousness Studies, 1, 32-37.

Bergson, H. (1911). Matter and memory (Paul, N. M., and Palmer, W. S., trans.). London, England: George Allen and Unwin. (Original work published in French in 1908)

Besant, A. (n.d.). Man and his bodies (Theosophical manuals no. 7). London, England: Theosophical Publishing House.

Blackmore, S. J. (1982). Beyond the body: An investigation of out-of-the-body experiences. London, England: Heinemann.

Blackmore, S. J. (1984). A psychological theory of the out-of-body experience. Journal of Parapsychology, 48, 201-218.

Blackmore, S. J. (1993). Dying to live: Science and the near-death experience. London, England: Grafton.

Blanke, O., Landis, T., Spinelli, L., and Seeck, M. (2004). Out-of-body experience and autoscopy of neurological origin. Brain, 127, 243-258.

Blanke, O., Ortigue, S., Landis, T., and Seeck, M. (2002). Stimulating illusory own-body perceptions. Nature, 419, 269-270.

Bouvéry, J. (1897). Le spiritisme et l'anarchie devant la science et la philosophie [Spiritism and anarchy in front of science and philosophy]. Paris, France: Chamuel.

Bozzano, E. (1903). Ipotesi spiritica e teorie scientifiche [Spiritist hypothesis and scientific theory]. Genova, Italy: A. Donath.

Bozzano, E. (1906). Mrs. Piper et la conscience subliminal: Comment le seul fait l'existence des phénomènes métapsychiques, considérés en rapport avec la loi de l'évolution et sans tenir compte de l'hypothèse spirite, suffit à démontrer la survie de l'esprit après la mort du corps [Mrs. Piper and the subliminal consciousness: How the single fact of the existence of metapsychic phenomena, considered in relation to the law of evolution and without considering the spiritist hypothesis, is enough to demonstrate the survival of the spirit after death]. Annales des Sciences Psychiques, $16,529-568$.

Bozzano, E. (1907). Symbolism and metapsychical phenomena. Annals of Psychical Science, 6, 235-259 and 335-366.

Bozzano, E. (1911). Considerations et hypothéses sur les phénomènes de "bilocation" [Considerations and hypotheses about the phenomena of "bilocation"]. Annales des Sciences Psychiques, 21, 65-72, 109-116, 143-152, and 166-172.

Bozzano, E. (1923a). Facoltà supernormali subconscienti ed evoluzione biologica della 
specie [Supernormal subconscious faculties and the species' biological evolution]. Luce e Ombra, 23, 221-236.

Bozzano, E. (1923b). L'hypothése spirite et la "cryptesthesia" [The spirit hypothesis and "cryptesthesia"]. Revue Métapsychique, No. 4, 236-246.

Bozzano, E. (1923c). Phénomènes psychiques au moment de la mort [Psychic phenomena at the moment of death]. Paris, France: Éditions de la B. P. S.

Bozzano, E. (1924). Autobiographical sketch. Journal of the American Society for Psychical Research, 18, 153-155.

Bozzano, E. (1925a). Cerveau et pensée [Brain and thought]. Revue Spirite, 68, 105-108 and 151-157.

Bozzano, E. (1925b). Des communications médiümniformes entre vivants [Mediumisticlike communications between the living]. Revue Métapsychique, No. 5, 308-325.

Bozzano, E. (1925c). Los fenómenos de encantamiento [The phenomena of hauntings] (Champs d'Or, A., trans.). Barcelona, Spain: Bauzá. (Original work published 1919)

Bozzano, E. (1926). A propos de l'introduction à la métapsychique humaine [Regarding the introduction to human metapsychics]. Paris, France: Jean Meyer.

Bozzano, E. (1927). Des manifestations supranormales chez les peuples sauvages [Supranormal manifestations in primitive people]. Paris, France: Jean Meyer.

Bozzano, E. (1929). Pensée et volonté [Thought and will]. Paris, France: Jean Meyer. (Original work published 1926-1927)

Bozzano, E. (1933). Considerations et hypothéses au sujet des phénomènes télèpathiques [Considerations and hypotheses on the topic of telepathic phenomena] Revue Métapsychique, No. 3, 145-158.

Bozzano, E. (1934a). "Corpo eterico" ed esistenza spirituale [The "etheric body" and spiritual existence]. La Ricerca Psichica, 34, 582-595.

Bozzano, E. (1934b). Dei fenomeni di "transfigurazione" [The phenomena of "transfiguration"] La Ricerca Psichica, 34, 65-76, 140-150, 264-276, and 330-342.

Bozzano, E. (1937). Les phénomenes de bilocation [The phenomena of bilocation] (Gobron, G., trans.). Paris, France: Jean Meyer. (Original work published 1934)

Bozzano, E. (ca. 1938). Discarnate influence in human life: A review of the case for spirit intervention (Emerson, I., trans.). London, England: International Institute for Psychical Research/John M. Watkins.

Bozzano, E. (1942). Dei fenomeni di telestesia [The phenomena of telesthesia]. Verona, Italy: L'Albero.

Bozzano, E. (1952). La crisi della morte [The crisis of death]. Milan, Italy: Fratelli Bocca

Bozzano, E. (1967). Animismo o spiritismo? Quale tra i due spiega il complesso dei fatti? [Animism or spiritism? Which of the two explains the ensemble of facts?]. Verona, Italy: Luce e Ombra. (Original work published 1938)

Bozzano, E. (1982). Musica transcendentale [Transcendental music]. Rome, Italy: Mediterranee. (Original work published 1943)

Braude, S. E. (2003). Immortal remains: The evidence for life after death. Lanham, MD: Rowman and Littlefield.

Bret, P. T. (1938). Les métapsychoses: La métapsychorragie, la telépathie, la hantise: Vol. 1: Introduction et la métapsychorragie fantasmale [The metapsychoses: Metapsychorrhagy, telepathy, hauntings: Vol. 1: Introduction to phantom metapsychorrhagy]. Paris, France: J.-B. Baillière.

Brugger, P. (2002). Reflective mirrors: Perspective-taking in autoscopic phenomena. Cognitive Neuropsychiatry, 7, 179-194.

Brugger, P. (2003). Supernumerary phantoms: A comment on Grossi et al.'s (2002) "Spare thoughts on spare limbs." Perceptual and Motor Skills, 97, 3-10.

Chardel, C. M. M. P. C. (1818). Mémoire sur le magnétisme animal, presenté a l'Académie de Berlin, en 1818 [Memoir on animal magnetism, presented to the Academy of Berlin, in 1818]. Paris, France: Badouin.

Charpignon, J. (1851). Physiologie, médicine et métaphysique du magnétisme [Physiol- 
ogy, medicine and metaphysics of magnetism]. Brussels, Belgium: Société Typographique Belgue.

Committee of the London Dialectical Society. (1871). Report on Spiritualism, of the Committee of the London Dialectical Society, together with the evidence, oral and written, and a selection from the correspondence. London, England: Longmans, Green, Reader and Dyer.

Costa, G. (1923). Di là dalla vita (La relatività della morte) [On life (The relativity of death)]. Torino, Italy: Lattes.

Crookall, R. (1967). Events on the threshold of the after-life: "Clues" as to "the greatest of all enigmas." Moradabad, India: Darshana International.

Crookes, W. (1874). Researches in the phenomena of spiritualism. London, England: J. Burns.

Crowe, C. (1848). The night-side of nature; or, ghosts and ghost seers (2 vols.). London, England: T.C. Newby.

D'Assier, A. (1887). Posthumous humanity: A study of phantoms (Olcott, H. S. trans.) London, England: George Redway. (Originally work published 1883)

Davis, A. J. (1868). Death and the after-life: Eight evening lectures on the Summer-land (revised ed.). Boston, MA: Colby and Rich.

Delanne, G. (1909). Les apparitions matérialisées des vivants et des morts [Materialized apparitions of the living and the dead] (Vol. 1). Paris, France: Leymarie.

Dening, T. R., and Berrios, G. E. (1994). Autoscopic phenomena. British Journal of Psychiatry, 165, 808-817.

De Rochas, A. (1895). Les fantômes des vivants [Phantoms of the living]. Annales des Sciences Psychiques, 5, 257-275.

De Rochas, A. (1897). Les expériences de Choisy-Yvrac (près Bordeaux) du 2 au 14 octobre 1896 [Tests at Choisy-Yvrac (near Bordeaux) from 2 to 14 October 1896]. Annales des Sciences Psychique, 7, 6-28.

Deveney, J. P. (1997). Astral projection or liberation of the double and the work of the early Theosophical Society (Theosophical history occasional paper, Vol. 6). Fullerton, CA: Theosophical History.

De Vesme, C. (1934). [Review of La Mediumnité Polyglote (Polyglot mediumship), by E. Bozzano]. Revue Métapsychique, No. 4, 265-270.

De Vesme, C. (1935). Eloge de l'ignorance en métapsychique [Praising ignorance in metapsychics]. Revue Métapsychique, No. 5, 369-393.

Driesch, H. (1933). Psychical research: The science of the super-normal (Besterman, T., trans.). London, England: G. Bell. (Original work published 1932)

Durville, H. (1909). Le fantome des vivants: Anatomie et physiologie de l'ame: Recherches experimentales sur le dédoublement des corps de l'homme [The phantom of the living: Anatomy and physiology of the soul: Experimental investigations of the doubling of the bodies of man]. Paris, France: Librairie du Magnétisme.

Evans, H. (2004). Seeing ghosts: Experiences of the paranormal. London, England: John Murray.

Finger, S. (2000). Minds behind the brain: A history of the pioneers and their discoveries. Oxford, England: Oxford University Press.

Flammarion, C. (1900). L'inconnu: The unknown. New York, NY: Harper and Brothers.

Fodor, N. (1966). Encyclopaedia of psychic science. New Hyde Park, NY: University Books. (Original work published 1933)

Fontana D. (2005). Is there an afterlife? Hants, England: O Books.

Fox, O. (1920). The pineal doorway: A record of research. Occult Review, 31, 190-198.

Fraser, C. (2002). Fact and fiction: A clarification of phantom limb phenomena. British Journal of Occupational Therapy, 65, 256-260.

Fugairon, L. S. (1907). La survivance de l'ame ou la mort et la renaissance chez les êtres vivantes: Etudes de physiologie et d'embryologie philosophiques [The survival of the 
soul or the death and rebirth of living beings: Physiology and philosophical embryology studies]. Paris, France: Librairie du Magnétisme.

Funk, I. (1907). The psychic riddle. New York, NY: Funk and Wagnalls.

Gauld, A. (1968). The founders of psychical research. London, England: Routledge and Kegan Paul.

Gauld, A. (1982). Mediumship and survival: A century of investigations. London, England: Heinemann.

Geley, G. (1927). Clairvoyance and materialisation: A record of experiments. London, England: T. Fisher Unwin. (Original work published 1924)

Geley, G. (ca. 1920). From the unconscious to the conscious. (de Brath, S., trans.). New York, NY: Harper and Brothers. (Original work published 1919)

Girard, T. A., and Cheyne, J. A. (2004). Individual differences in lateralisation associated with sleep paralysis. Laterality: Asymmetries of Body, Brain and Cognition, 9, 93-111.

Gregorio, O. (2004). La bilocazione nella vita di sant'Alfonso de' Liguori [Bilocation in the life of Saint Alfonso de Liguori]. Luce e Ombra, 104, 13-31.

Greyson, B. (2000). Dissociation in people who have near-death experiences: Out of their bodies or out of their minds? Lancet, $355,460-463$.

Grosso, M. (2004). Experiencing the next world now. New York: Paraview Pocket Books.

Grotstein, J. S. (1983). Autoscopy: The experience of oneself as a double. Hillside Journal of Clinical Psychiatry, 5, 259-304.

Guépin, A. (1915a). Destruction, par suppuration et ablation, d'une notable partie du cerveau; aucun trouble appréciable consécutif [Destruction, by suppuration and ablation, of a large part of the brain; without any following disorder]. Compte rendus hedbomadaires des séances de l'Académie des Sciences, 160, 400-402.

Guépin, A. (1915b). Enfoncement de l'occipital gauche (par éclat d'obus): Abcès du cerveau et encéphalocèle récidivante; ablation chirurgicale (amputation) ou destruction d'un tiers de l'hémisphère cérébrale gauche; guérison sans troubles nerveux consécutivs appréciables [Sinking of the left occipital (by shell shattering): Brain abscess and relapsed encephalocele; surgical ablation (amputation) or destruction of a third part of the left cerebral hemisphere; healing without consecutive appreciable nervous problems]. Compte rendus hedbomadaires des séances de l'Académie des Sciences, 161, 703-704.

Gurney, E., Myers, F. W. H., and Podmore, F. (1886). Phantasms of the living (2 vols). London, England: Trübner.

Haddock, J. W. (1851). Somnolism and psycheism; or, the science of the soul and the phenomena or nervation (2nd ed.). London, England: James S. Hodson.

Halligan, P. W. (2002). Phantom limbs: The body in mind. Cognitive Neuropsychiatry, 7, 251-269.

Hare, R. (1855). Experimental investigations of the spirit manifestations, demonstrating the existence of spirits and their communion with mortals. New York, NY: Partridge and Brittan.

Harrison, W. H. (1879). Spirits before our eyes. London, England: W. H. Harrison.

Hart, H. (1954). ESP projection: Spontaneous cases and the experimental method. Journal of the American Society for Psychical Research, 48, 121-146.

Hart, H., and associated collaborators. (1956). Six theories of apparitions. Proceedings of the Society for Psychical Research, 50, 153-239.

Holms, A. C. (1927). The facts of psychic science and philosophy collated and discussed. Jamaica, NY: Occult Press.

Iannuzzo, G. (1983). Ernesto Bozzano: La vita e l'opera [Ernesto Bozzano: Life and work] (Le Monografie di Luce e Ombra, No. 2). Verona: Luce e Ombra.

Inglis, B. (1992). Natural and supernatural: A history of the paranormal from earliest times to 1914 (rev. ed.). Dorset, England: Prism Press. 
Irwin, H. J. (1985). Flight of mind: A psychological study of the out-of-body experience. Metuchen, NJ: Scarecrow Press.

Irwin, H. J. (2000). The disembodied self: An empirical study of dissociation and the outof-body experience. Journal of Parapsychology, 64, 261-277.

James, W. (1898). Human immortality: Two supposed objections to the doctrine. Boston, MA: Houghton, Mifflin.

Johnson, R. C. (1953). The imprisioned splendour: An approach to reality, based upon the significance of data drawn from the fields of natural science, psychical research. London, England: Hodder and Stoughton.

Judge, W. Q. (1893). The ocean of theosophy. New York, NY: The Path.

Jung-Stilling, J. H. (1851). Theory of pneumatology; in reply to the question, what ought to be believed or disbelieved concerning presentiments, visions, and apparitions, according to nature, reason and scripture (1st American ed.) (Jackson, S., trans., Bush, G., ed.). New York, NY: J. S. Redfield.

Kardec, A. (1863). Spiritisme expérimental: Le livre des médiums, ou guide des médiums et des évocateurs [Experimental spiritism: The book of mediums, or guide for mediums and their invocators] (6th ed.). Paris, France: Didier.

Kerner, J. (1845). The seeress of Prevost: Being revelations concerning the inner-life of man, and the inter-diffusion of a world of spirits in the one we inhabit. (Crowe, C., trans.). London, England: J. C. Moore.

Lancelin, C. (1986). Méthode de dédoublement personnel (Extériorisation de la neuricite: Sorties en astral) [Method of personal doubling (Exteriorization of neuricity: Astral excursions)]. (3rd ed.). Paris, France: Fernand Lanore. (Original work published 1913)

Larsen, C. D. (1927). My travels in the spirit world. Rutland, VT: Tuttle.

Luckhurst, R. (2002). The invention of telepathy 1870-1901. Oxford, England: Oxford University Press.

McAdams, E. (1984). Reported near-death observations in a hospice in California. In Rose, M. C. (Ed.) The synergy of religion and psychical research (pp. 57-64). Bloomfield, CT: Academy of Religion and Psychical Research.

MacDougall, D. (1907). Hypothesis concerning soul substance together with experimental evidence of the existence of such substance. Journal of the American Society for Psychical Research, 1, 237-244.

McGonigle, D. J., Hänningen, R., Salenius, S., Hari, R., Frackowiack, R. S. J., and Frith, C. D. (2002). Whose arm is it anyway? An fMRI case study of supernumerary phantom limb. Brain, 125, 1265-1274.

Mattiesen, E. (1931). Der Austritt des Ich als spiritistisches Argument [The excursion of the I as a spiritistic argument]. Zeitschrift fur Parapsychologie, 6, 413-437 and 481494.

Mattiesen, E. (1936-1939). Das persönliche Überleben des Todes: Eine Darstellung der Erfahrungsbeweise [Personal survival of death: A presentation of the empirical evidence] ( 3 vols.) Berlin, Germany: Walter de Gruyter.

Mead, G. R. S. (1919). The doctrine of the subtle body in Western tradition. London, England: J. M. Watkins.

Melzak, R. (1989). Phantom limbs, the self and the brain. Canadian Psychology, 30, $1-16$.

Meyer, J. (1928). Discours de M. Jean Meyer [Lecture of Mr. Jean Meyer]. Revue Spirite, $71,439-441$.

Monk, D. (1922). The process of dying witnessed by eight persons: Visible evidences of the spirit body. Light, 42, 182.

Muldoon, S. J., and Carrington, H. (1929). The projection of the astral body. London, England: Rider.

Muldoon, S. J., and Carrington, H. (1951). The phenomena of astral projection. London, England: Rider. 
Murray, C., and Fox, J. (2005). The out-of-body experience and body image: Differences between experients and nonexperients. Journal of Nervous and Mental Disease, 193, 70-72.

Myers, F. W. H. (1886). Note on a suggested mode of psychical interaction. In Gurney, E., Myers, F. W. H., and Podmore, F., Phantasms of the living (pp. 277-316, Vol. 2). London, England: Trübner.

Myers, F. W. H. (1892). On indications of continued terrene knowledge on the part of phantasms of the dead. Proceedings of the Society for Psychical Research, 8, 170-252.

Myers, F. W. H. (1903). Human personality and its survival of bodily death (2 vols.). London, England: Longmans, Green.

Osty, E. (1930). La vision de soi [Seeing the self]. Revue Métapsychique, No. 3, 185-197.

Oxon, M. A. [pseudonym of Moses, W.S.]. (1876, March 5). Photographing the spirit of a medium in Paris, while his body was asleep in London. Spiritualist Newspaper, p. 119.

Papus, Dr. [pseudonym of Encausse, G.]. (1900). Comment est constitue l'etre humain?: Le corps - Le astral - L'esprit et leurs correspondances [How is the human being constituted? The body - The astral - The spirit and its correspondences]. Paris, France: L'Initiation/Chamuel.

Poortman, J. J. (1978). Vehicles of consciousness: The concept of hylic pluralism (Ochema). (Smith, N. D., trans.) Utrecht, The Netherlands: Theosophical Society in the Netherlands. (Original work published, 1954)

Popper, K. R., and Eccles, J. C. (1977). The self and its brain: An argument for interactionism. London, England: Springer.

Ravaldini, S. (1993). Ernesto Bozzano e la ricerca psichica: Vita e opere di un pioniere della parapsicologia [Ernesto Bozzano and psychical research: Life and work of a pioneer in parapsychology]. Rome, Italy: Mediterranee.

Richet, C. (1922). Traité de métapsychique [Treatise on metapsychics] Paris, France: Félix Alcan.

Richet, C. (1924). For and against survival: The difficulty of survival from the scientific point of view. Proceedings of the Society for Psychical Research, 34, 107-113.

Ring, K. (1980). Life at death: A scientific investigation of the near-death experience. New York, NY: Coward, McCann and Geoghegan.

Ring, K., and Lawrence, M. (1993). Further evidence for veridical perception during near-death experiences. Journal of Near-Death Studies, 11, 223-229.

Roll, W. G. (1982). The changing perspective of life after death. In Krippner, S. (Ed.), Advances in parapsychological research: Vol. 3 (pp. 147-291). New York, NY: Plenum Press.

Saltmarsh, H. F. (1938). [Review of Discarnate influence on human life, by E. Bozzano]. Journal of the Society for Psychical Research, 30, 277-278.

Schrenck-Notzing, A. F. de. (1925). Les phénomènes physiques de la médiumnité (Longaud, E., trans). Paris, France: Payot. (Original work published 1920)

Sheldrake, R. (2003). The sense of being stared at and other aspects of the extended mind. New York, NY: Three Rivers Press.

Siegel, R. K. (1980). The psychology of life after death. American Psychologist, 35, 911-931.

Siegel, R. K., and Hirschman, A. E. (1983). Bozzano and the first classification of deathbed visions: A historical note and translation. Anabiosis: The Journal of NearDeath Studies, 3, 195-201.

Simons, C. E. G. (1894). Correspondence. Journal of the Society for Psychical Research, $6,287-288$.

Snell, J. (1918). The ministry of angels: Here and hereafter. London, England: G. Bell and Sons.

Sollier, P. (1903). Les phénomènes d'autoscopie [The phenomena of autoscopy]. Paris, France: Félix Alcan. 
Sperry, R. W. (1993). The impact and promise of the cognitive revolution. American Psychologist, 48, 878-885.

Stead, W. T. (1896). Two doubles I have seen. Borderland, 3, 24-36.

Stevenson, I., and Greyson, B. (1979). Near-death experiences: Relevance to the question of survival after death. Journal of the American Medical Association, 242, 265-267.

Sudre, R. (1926). Introduction a la métapsychique humaine [Introduction to human metapsychics]. Paris, France: Payot.

Thouless, R. H., and Wiesner, B. P. (1947). The psi process in normal and "paranormal" psychology. Proceedings of the Society for Psychical Research, 48, 177-196.

Troude, R. (1920). Cerveau et pensée: Les enseignements récents de la pathologie de guerre [Brain and thought: The recent teachings of war pathology]. Revue Scientifique, $58,359-363$.

Turvey, V. (ca. 1911). The beginnings of seership; or, super-normal mental activity. London, England: Stead's Publishing House.

Wills-Brandon, C. (2000). One last hug before I go: The mystery and meaning of deathbed visions. Deerfield Beach, FL: Health Communications.

Wright, J. P., and Potter, P. (Eds.).(2000). Psyche and soma: Physicians and metaphysicians on the mind-body problem. Oxford, England: Oxford University Press.

Young, R. M. (1970). Mind, brain and adaptation in the nineteenth century: Cerebral localization and its biological context from Gall to Ferrier. Oxford, England: Clarendon Press.

Zaleski, C. (1987). Otherworld journeys: Accounts of near-death experience in medieval and modern times. New York, NY: Oxford University Press. 